\title{
Virulence of Mycobacterium tuberculosis and Susceptibility to Peroxidative Killing Systems
}

\author{
By P. S. JACKETT, V. R. ABER AND D. B. LOWRIE \\ MRC Unit for Laboratory Studies of Tuberculosis, \\ Royal Postgraduate Medical School, Du Cane Road, London W12 0HS
}

(Received 14 February 1978)

\begin{abstract}
At sub-bactericidal concentrations of hydrogen peroxide, Mycobacterium tuberculosis was killed by hydrogen peroxide/peroxidase/halide microbicidal systems. The halide cofactor could be either iodide or, with much lower efficiency, chloride. Omission of any one of the reactants eliminated the tuberculocidal effect. Differences in susceptibility between different strains of $M$. tuberculosis did not correlate with virulence differences. The observations are discussed in the context of host defence mechanisms against tuberculosis.
\end{abstract}

\section{INTRODUCTION}

How macrophages kill Mycobacterium tuberculosis is not yet established. Hydrogen peroxide $\left(\mathrm{H}_{2} \mathrm{O}_{2}\right)$ is produced by macrophages (Klebanoff \& Hamon, 1975) and resistance to it is a virulence determinant in $M$. tuberculosis (Mitchison et al., 1963). However, studies of strains with high virulence and of strains with low virulence, either on primary isolation from Indian patients (group 1) or after mutation to isoniazid resistance (group 2) or after prolonged maintenance on laboratory media (group 3), showed that possession of peroxide resistance, although necessary, is not sufficient for virulence (Jackett et al., 1978). In particular, the resistance of the laboratory-attenuated strain $\mathrm{H} 37 \mathrm{Ra}$ to $\mathrm{H}_{2} \mathrm{O}_{2}$ is comparable to that of virulent strains. This suggests that resistance to additional bactericidal macrophage products might also be required. However, virulence does not correlate with resistance to low pH or to superoxide (Jackett et al., 1978).

Since Reiter et al. (1964) and Klebanoff \& Luebke (1965) demonstrated the antibacterial effect of the reaction between $\mathrm{H}_{2} \mathrm{O}_{2}$, peroxidase and thiocyanate, leucocytic peroxidase (myeloperoxidase) has come to be regarded as a major component of antimicrobial host defences, acting by greatly enhancing the killing power of $\mathrm{H}_{2} \mathrm{O}_{2}$ in the presence of an oxidizable cofactor. The latter can be a halide or thyroxine instead of thiocyanate (Klebanoff \& Hamon, 1972; Klebanoff, 1975). It is not clear, however, whether such a system operates in macrophages. The peroxidase content of macrophages is low relative to that of polymorphonuclear phagocytes (Klebanoff \& Hamon, 1975). If the virulence of $M$. tuberculosis could be shown to correlate with resistance to a peroxidative killing system, then evidence would be forthcoming for such a system, present in macrophages, having a significant function. The strains of $M$. tuberculosis which had been compared previously for their resistance to low $\mathrm{pH}$, superoxide and $\mathrm{H}_{2} \mathrm{O}_{2}$ were therefore examined for susceptibility to peroxidasemediated killing systems using concentrations of $\mathrm{H}_{2} \mathrm{O}_{2}$ which were themselves sub-bactericidal. 


\section{METHODS}

Organisms. Six strains of Mycobacterium tuberculosis and Escherichia coli B were used. The origins and properties of the $M$. tuberculosis strains have been described previously (Jackett et al., 1978). Briefly, two strains (12646 and 79499) were of high virulence and four (H37Ra, B1453, 79112 and its isoniazid-resistant mutant 79112R) were of low virulence in the guinea pig. Both high-virulence strains were catalase-positive and $\mathrm{H}_{2} \mathrm{O}_{2}$-resistant. Of the low-virulence strains, $\mathrm{H37Ra}$ (group 3) and 79112 (group 1) were catalase-positive; B1453 (group 2) and 79112R were catalase-negative. $\mathrm{H37Ra}$ was resistant to $\mathrm{H}_{2} \mathrm{O}_{2}$; the other three were sensitive to $\mathrm{H}_{2} \mathrm{O}_{2}$.

Growth conditions. Mycobacterium tuberculosis was grown at $37^{\circ} \mathrm{C}$ in catalase-free liquid medium $7 \mathrm{H} 9$ (Jackett et al., 1978). For most tests, late-exponential phase ( $7 \mathrm{~d}$ ) cultures containing about $1 \times 10^{8}$ colonyforming units (c.f.u.) $\mathrm{ml}^{-1}$ were used. Mid-exponential phase $(4 \mathrm{~d})$ cultures containing about $1 \times 10^{7}$ c.f.u. $\mathrm{ml}^{-1}$ were used where stated. For tests with $E$. coli $\mathbf{B}$, late-exponential phase $(3 \mathrm{~h})$ cultures grown at $37^{\circ} \mathrm{C}$ in nutrient broth (Oxoid no. 2) to a concentration of $2 \times 10^{8}$ c.f.u. $\mathrm{ml}^{-1}$ were used.

Peroxidative system susceptibility tests. In the basic susceptibility tests, bacterial survival was assessed in the presence of three reactants: (i) lactoperoxidase, (ii) an oxidizable cofactor which was either iodide, chloride, thiocyanate or thyroxine, and (iii) $\mathrm{H}_{2} \mathrm{O}_{2}$ added as reagent or generated in situ by glucose oxidasecatalysed oxidation of glucose. Controls in which individual components of the reaction mixture were omitted were included in each experiment. In the standard peroxidative killing tests of Klebanoff (1970), lactate buffer at the optimum pH 4.5 to 5.0 is used. However, this buffer was found to be toxic to $M$. tuberculosis and so tests were done in a non-toxic buffer composed of $50 \mathrm{~mm}$-citric acid/50 mM-sodium phosphate (pH

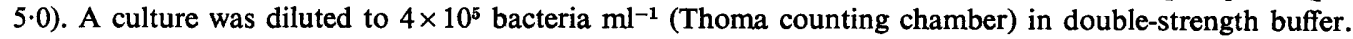
Samples of bacterial suspension $(500 \mu \mathrm{l})$ were dispensed into $75 \times 10 \mathrm{~mm}$ glass tubes and $200 \mu \mathrm{l} 50 \mathrm{mM}$ glucose in water was added to each tube. Lactoperoxidase ( 200 or $400 \mathrm{U}$ ), oxidizable cofactor (various amounts) and glucose oxidase $(0.005$ to $0.28 \mathrm{U})$ or reagent $\mathrm{H}_{2} \mathrm{O}_{2}(250 \mathrm{nmol})$ were added as separate $100 \mu \mathrm{l}$ solutions in water. Where reactants were omitted for control purposes, water was added to bring the final reaction volume to $1 \mathrm{ml}$. All reaction tubes were prepared in duplicate and glucose oxidase or $\mathrm{H}_{2} \mathrm{O}_{2}$ was added last. After $1 \mathrm{~h}$ incubation in a $37^{\circ} \mathrm{C}$ water bath, $100 \mu \mathrm{l}$ samples were removed, diluted 10 - and 100-fold in $0.1 \%(\mathrm{w} / \mathrm{v})$ bovine serum albumin fraction V (Armour Pharmaceuticals, Eastbourne, Sussex) and c.f.u. $\mathrm{ml}^{-1}$ were assessed on blood agar base (Oxoid) or $7 \mathrm{H} 11$ agar (Jackett et al., 1978) for E. coli and M. tuberculosis, respectively. The number of c.f.u. in a test mixture was expressed as a percentage of the number of c.f.u. in the corresponding control tubes which contained bacteria, glucose and buffer only. The figure so obtained was termed the percentage survival. The statistical significance of differences in percentage survival in different test conditions was assessed by analysis of variance.

Test reagents. Glucose oxidase (type $\mathrm{V})$ containing about $200 \mathrm{U}$ (mg protein) $)^{-1}$ was obtained from Sigma. One unit oxidizes $1 \mu \mathrm{mol} \beta$-D-glucose to D-glucuronic acid and $\mathrm{H}_{2} \mathrm{O}_{2}$ per min at pH $5 \cdot 1$ and $35^{\circ} \mathrm{C}$. Lactoperoxidase (Boehringer) contained $90 \mathrm{U}(\mu \mathrm{g} \text { protein })^{-1}$, standardized with $o$-dianisidine as substrate (Klebanoff, 1965). DL-Thyroxine and potassium thiocyanate were obtained from Sigma. All other reagents were of analytical grade (BDH).

\section{RESULTS}

In all experiments in which a bactericidal effect was seen with a complete mixture of $\mathrm{H}_{2} \mathrm{O}_{2}$ (or glucose oxidase), peroxidase and an oxidizable cofactor, omission of any one of the reactants eliminated the killing effect. For brevity, the results with these controls are not presented.

\section{Killing of $E$. coli}

Preliminary experiments with $E$. coli confirmed that each of the oxidizable cofactors, iodide, chloride, thiocyanate or thyroxine, was effective in peroxidative killing (Table 1). Iodide was more effective than the other cofactors. Essentially identical results were obtained when the organism was grown in $7 \mathrm{H} 9$ medium or tested in $100 \mathrm{~mm}$-lactate buffer $\mathrm{pH} 5.0$ (not shown).

\section{Killing of $M$. tuberculosis}

Susceptibility with iodide as cofactor. Mycobacterium tuberculosis was killed by the interaction of $\mathrm{H}_{2} \mathrm{O}_{2}$ (enzymically generated or added), lactoperoxidase and $10 \mu \mathrm{M}$-iodide (Table 1). Even with $1 \mu \mathrm{M}$-iodide the system was effective, the percentage survival in the complete $1 \mu$ M-iodide system being significantly different $(P<0.05$; all strains considered 
Table 1. Susceptibility of five strains of M. tuberculosis and E. coli в to peroxidative enzyme systems

Bacterial suspensions $\left(2 \times 10^{5}\right.$ bacteria $\left.\mathrm{ml}^{-1}\right)$ were incubated with glucose $(10 \mathrm{~mm})$ for $1 \mathrm{~h}$ at $37^{\circ} \mathrm{C}$, at pH 5.0, in $50 \mathrm{~mm}$-citric acid $/ 50 \mathrm{~mm}$-sodium phosphate. Tests and controls (organisms in glucose buffer only) were incubated in duplicate in two experiments. Survival in test conditions is expressed as a percentage of the survival in controls, i.e.

$\frac{\text { c.f.u. } \mathrm{ml}^{-1} \text { in test conditions }}{\text { c.f.u. } \mathrm{ml}^{-1} \text { in buffer control }} \times 100$; each value is the geometric mean of four estimates.

Test conditions

\begin{tabular}{|c|c|c|c|c|c|c|c|c|}
\hline \multirow[b]{2}{*}{$\begin{array}{c}\text { Glucose } \\
\text { oxidase } \\
\left(\mathrm{U} \mathrm{ml} \mathrm{ml}^{-1}\right)\end{array}$} & \multicolumn{2}{|l|}{ Tonto } & \multicolumn{6}{|c|}{ Mean percentage survival } \\
\hline & $\begin{array}{l}\text { Lacto- } \\
\text { peroxidase } \\
\left(\mathrm{U} \mathrm{ml}^{-1}\right)\end{array}$ & $\begin{array}{c}\text { Cofactor } \\
(\mu \mathrm{M})\end{array}$ & $\begin{array}{r}\text { I2646 } \\
(\mathrm{H})^{*}\end{array}$ & $\begin{array}{c}79499 \\
(\mathrm{H})\end{array}$ & $\begin{array}{c}\text { H37Ra } \\
(L)^{*}\end{array}$ & $\begin{array}{c}\text { B1453 } \\
\text { (L) }\end{array}$ & $\begin{array}{c}79112 \\
\text { (L) }\end{array}$ & E. coli $\mathrm{B}$ \\
\hline $\begin{array}{l}0 \cdot 02 \\
0 \cdot 28\end{array}$ & $\begin{array}{l}- \\
-\end{array}$ & $\begin{array}{l}- \\
-\end{array}$ & $\begin{array}{l}97 \\
93\end{array}$ & $\begin{array}{l}87 \\
80\end{array}$ & $\begin{array}{l}116 \\
105\end{array}$ & $\begin{array}{l}82 \\
79\end{array}$ & $\begin{array}{r}103 \\
68\end{array}$ & $\begin{array}{l}95 \\
50\end{array}$ \\
\hline $\begin{array}{l}0.02 \\
0.02\end{array}$ & $\begin{array}{l}200 \\
200\end{array}$ & $\begin{array}{l}\text { KI (1) } \\
\text { KI (10) }\end{array}$ & $\begin{aligned} & 55 \\
< & 0 \cdot 1\end{aligned}$ & $\begin{array}{l}48 \\
<0.1\end{array}$ & $\begin{array}{l}100 \\
<0 \cdot 1\end{array}$ & $\begin{array}{c}54 \\
<0.1\end{array}$ & $\begin{array}{c}90 \\
<0.1\end{array}$ & $\begin{array}{c}52 \\
<0 \cdot 1\end{array}$ \\
\hline $\begin{array}{l}0.02 \\
0.28\end{array}$ & $\begin{array}{l}200 \\
200\end{array}$ & $\begin{array}{l}\mathrm{KCl}(100) \\
\mathrm{KCl}(100)\end{array}$ & $\begin{array}{l}80 \\
71\end{array}$ & $\begin{array}{r}107 \\
61\end{array}$ & $\begin{array}{r}103 \\
94\end{array}$ & $\begin{array}{l}58 \\
76\end{array}$ & $\begin{array}{r}56 \\
104\end{array}$ & $\begin{array}{l}50 \\
35\end{array}$ \\
\hline $\begin{array}{l}0.02 \\
0.02\end{array}$ & $\begin{array}{l}200 \\
200\end{array}$ & $\begin{array}{l}\text { Thyroxine (5) } \\
\text { Thiocyanate (625) }\end{array}$ & $\begin{array}{l}80 \\
89\end{array}$ & $\begin{array}{r}122 \\
91\end{array}$ & $\begin{array}{r}99 \\
102\end{array}$ & $\begin{array}{l}74 \\
88\end{array}$ & $\begin{array}{l}94 \\
97\end{array}$ & $\begin{array}{r}1.5 \\
<0.1\end{array}$ \\
\hline $\begin{array}{c}\mathrm{H}_{2} \mathrm{O}_{2} \\
(250 \mu \mathrm{M})\end{array}$ & 200 & KI (10) & $<0.1$ & $<0.1$ & $<0.1$ & $<0 \cdot 1$ & $<0.1$ & $<0.1$ \\
\hline
\end{tabular}

* $\mathbf{H}$ and $\mathbf{L}$, High and low virulence, respectively, in the guinea pig (root index of virulence $>1$ or $<1$; Mitchison et al., 1961).

Table 2. Effect of phase of growth and lactoperoxidase concentration on the susceptibility of six strains of $M$. tuberculosis to chloride-dependent peroxidative killing systems

Bacteria were grown to either the mid-exponential or late-exponential phase of growth and their survival in each killing system was assessed and expressed as described in Table 1.

Test conditions

\begin{tabular}{|c|c|c|c|c|c|c|c|c|}
\hline \multirow{2}{*}{$\begin{array}{l}\text { Glucose } \\
\text { oxidase } \\
\left(\mathrm{U} \mathrm{ml}^{-1}\right)\end{array}$} & \multirow{2}{*}{$\begin{array}{l}\text { Lacto- } \\
\text { peroxidase } \\
\left(\mathrm{U} \mathrm{ml}^{-1}\right)\end{array}$} & \multirow{2}{*}{$\begin{array}{c}\mathrm{KCl} \\
(\mathrm{mM})\end{array}$} & \multicolumn{6}{|c|}{ Mean percentage survival } \\
\hline & & & $\mathbf{I} 2646$ & 79499 & H37Ra & B1453 & 79112 & $79112 \mathrm{R}$ \\
\hline & & & \multicolumn{6}{|c|}{ Mid-exponential phase } \\
\hline $0 \cdot 28$ & - & - & 72 & 96 & 102 & 90 & 98 & $92 *$ \\
\hline \multirow[t]{2}{*}{$0 \cdot 28$} & $\begin{array}{l}200 \\
400\end{array}$ & $\begin{array}{l}100 \\
100\end{array}$ & $\begin{array}{l}55 \\
46\end{array}$ & $\begin{array}{l}89 \\
81\end{array}$ & $\begin{array}{l}70 \\
56\end{array}$ & $\begin{array}{l}91 \\
67\end{array}$ & $\begin{array}{l}29 \\
25\end{array}$ & $\begin{array}{l}50^{*} \\
38^{*}\end{array}$ \\
\hline & & & \multicolumn{6}{|c|}{ Late-exponential phase } \\
\hline $\begin{array}{l}0.005 \\
0.28\end{array}$ & - & $\begin{array}{l}- \\
-\end{array}$ & $\begin{array}{c}101 \dagger \\
97\end{array}$ & $\begin{array}{c}119 \dagger \\
94\end{array}$ & $\begin{array}{c}113 \dagger \\
84\end{array}$ & $\begin{array}{l}99+ \\
100\end{array}$ & $\begin{array}{c}112 \dagger \\
92\end{array}$ & $\begin{array}{l}98 \\
0.4 \dagger\end{array}$ \\
\hline $0 \cdot 28$ & 200 & 100 & 63 & 80 & 66 & 100 & 97 & $85^{*}$ \\
\hline
\end{tabular}

together) from that in the glucose oxidase control. Although some strains were more susceptible than others, susceptibility did not correlate with either low virulence or suscep tibility to $\mathrm{H}_{2} \mathrm{O}_{2}$. Cofactors other than iodide were ineffective. Although there was some indication of an effect with $100 \mu \mathrm{M}$-chloride on some strains (Table 1), a series of experiments in which chloride was tested at 1 and $10 \mathrm{~mm}$ (in the presence of glucose oxidase at 0.02 or $0.28 \mathrm{U} \mathrm{ml}^{-1}$ and peroxidase at $200 \mathrm{U} \mathrm{ml}^{-1}$ ) failed to substantiate this effect. In contrast, 
chloride was consistently effective as cofactor in the peroxidative killing of $E$. coli (results not shown).

Susceptibility with chloride as cofactor. The glucose/glucose oxidase/lactoperoxidase/ chloride system was examined further in experiments in which the chloride concentration was increased to $100 \mathrm{mM}$ to more closely reflect physiological concentrations. Because bacteria are often most susceptible to bactericidal agents when they are growing most actively (Winslow \& Walker, 1939; Meynell, 1961), the effect of the phase of growth was also investigated. With this higher chloride concentration, a small bactericidal effect of the system against some strains was again seen (Table 2). Although mid-exponential phase cultures were no more susceptible to $\mathrm{H}_{2} \mathrm{O}_{2}$ (glucose oxidase control) than late-exponential phase cultures, the younger cultures of strains 79112 and 79112R showed greater susceptibility to the complete system than the older cultures, i.e. the difference in percentage survival between the glucose oxidase control and the complete system was greater with the younger than with the older cultures $(P<0.01$, for both strains). The phase of growth had no effect on the susceptibility of the other strains to the complete system. The bactericidal effect was increased when the peroxidase concentration was increased, i.e. the difference in percentage survival between the glucose oxidase control and the complete system was greater with 400 than with $200 \mathrm{U}$ peroxidase $\mathrm{ml}^{-1}(P<0.01$, over all strains). No correlation between the degree of killing and either virulence or $\mathrm{H}_{2} \mathrm{O}_{2}$ susceptibility of the strains was apparent.

\section{DISCUSSION}

The brief reports that mycobacteria, including $M$. tuberculosis, are susceptible to peroxidase-mediated killing with iodide (Demoulin-Brahy et al., 1975; Delville et al., 1976; Avila et al., 1976) are confirmed and extended here. Although iodide as low as $1 \mu \mathrm{M}$ is an effective cofactor for the peroxidase-mediated tuberculocidal reaction, this concentration may not be reached in macrophages. Thyroid hormones are regarded as a natural source of iodide for the killing system in granulocytes (Klebanoff, 1970) but the amounts of thyroid hormones or iodide in macrophages are not known. Hyperthyroidism, induced in rabbits by injection of either thyroxine or triiodothyronine, can enhance resistance to infection with $M$. tuberculosis (Lurie, 1964). Although no beneficial effect of triiodothyronine administration is observed in patients with pulmonary tuberculosis (Nodine et al., 1959), increased resistance is seen in guinea pigs (Bloch, 1963). Furthermore, macrophages from triiodothyroninetreated guinea pigs appear to suppress growth of $M$. tuberculosis to a greater extent than do macrophages from normal rabbits (Hsu \& Kapral, 1960). However, in the face of the complexity of the hormonally elicited changes, it is no more than a possibility that increased availability of iodide for a peroxidative killing system is involved. Because the availability of iodide for a tuberculocidal peroxidative reaction in vivo is questionable, it is particularly pertinent that in the in vitro system iodide can be replaced by chloride. Although the chloride dependent system is much less efficient (the halide concentration required for an equivalent tuberculocidal effect being $10^{5}$ times greater with chloride than with iodide), chloride is likely to be adequately available in macrophages (Klebanoff, 1970). Although the efficiency with which toxic products are generated from the $\mathrm{H}_{2} \mathrm{O}_{2}$ /peroxidase/chloride system is critically dependent on the ratios of the reactants (Sbarra et al., 1976, 1977), the system, unlike the iodide-dependent system (Klebanoff, 1967), can operate optimally even at neutral $\mathrm{pH}$. The tuberculocidal effect of the chloride-dependent reaction may therefore exceed that of the iodide-dependent reaction in the bacterial environment in vivo, particularly if low $\mathrm{pH}$ does not prevail.

The peroxidase-mediated systems in effect convert innocuous concentrations of $\mathrm{H}_{2} \mathrm{O}_{2}$ into tuberculocidal reactants. This raises the question of whether $M$. tuberculosis encounters peroxidase within macrophages. Briefly, peroxidase is present in granules (presumably lysosomes) in bone marrow promonocytes in man, mouse and guinea pig and in lesser 
amounts in circulating and exudative monocytes of the same species; it is less abundant than in polymorphonuclear leucocytes and essentially absent from the granules of mature macrophages in these species and in the rat and rabbit; however, peroxidase can perhaps transfer from granulocytes to macrophages during the complex cell interactions in inflammatory exudates (Klebanoff \& Hamon, 1975). The small amounts of peroxidase present in macrophage golgi vesicles and in nuclear and endoplasmic reticulum membranes are of doubtful relevance to microbial killing. Peroxidase is absent from granules of rabbit alveolar and mouse peritoneal macrophages (Biggar \& Sturgess, 1976; Lepper \& Hart, 1976) and alveolar macrophage bactericidal activity against Gram-positive and Gramnegative organisms is not peroxidase-mediated (Biggar et al., 1976). However, peroxidase can transfer from granules to phagocytic vesicles in casein-elicited peritoneal monocytes of the guinea pig (Daems et al., 1975) and mouse (Lepper \& Hart, 1976) and is involved in the ability of human monocytes to kill Candida (Lehrer, 1970). Thus, peroxidase may be potentially less available for tuberculocidal reactions in macrophages than in monocytes.

Monocytes produce $\mathrm{H}_{2} \mathrm{O}_{2}$ (Klebanoff \& Hamon, 1975) and therefore the peroxidase of monocytes might play an important role in killing $M$. tuberculosis in tuberculous granulomas of high cell-turnover type. These develop with the onset of cell-mediated immunity and immature macrophages or monocytes predominate (Dannenberg et al., 1972; Spector, 1975). Demonstration of a correlation between virulence and resistance to peroxidasemediated killing systems would have supported this view but absence of correlation, as found here, does not constitute evidence to the contrary. Mycobacterium tuberculosis might simply be less prone to vary in its resistance to peroxidative systems than in its resistance to other host defences, e.g. $\mathrm{H}_{2} \mathrm{O}_{2}$. It is nevertheless possible that the organism avoids exposure to peroxidase in vivo. The organism can inhibit fusion of lysosomes with the phagocytic vacuole in macrophages (Draper \& Hart, 1975; Lowrie et al., 1975) and possibly also in monocytes (Lepper \& Hart, 1976) when the phagocytes are in monolayer culture. Direct investigation of the extent of in vivo peroxidase exposure is clearly needed.

If a peroxidase $/ \mathrm{H}_{2} \mathrm{O}_{2}$ /halide tuberculocidal system does operate in vivo, the present study indicates that organisms with high and low virulence are likely to be equally susceptible to its effects. Low virulence in strain H37Ra (laboratory-attenuated, low-virulence group 3) therefore probably cannot be explained by loss of resistance to the peroxidase system. Previous studies also showed that this strain was not deficient in resistance to $\mathrm{H}_{2} \mathrm{O}_{2}$, low pH or superoxide, alone or in combination (Jackett et al., 1978). Hence, although low virulence of $M$. tuberculosis isolated from Indian patients or of isoniazid-resistant mutants (lowvirulence groups 1 and 2 respectively) can be attributed to loss of $\mathrm{H}_{2} \mathrm{O}_{2}$ resistance, the basis of low virulence in group 3 organisms is still uncertain.

The authors thank Professor D. A. Mitchison for helpful discussions.

\section{REFERENCES}

Avila, J. L., Convit, J., Pinardi, M. E. \& Jacques, P. J. (1976). Loss of infectivity of mycobacterial and protozoal exoplasmic parasites after exposure in vitro to the polyenzymic cocktail 'PIGO'. Biochemical Society Transactions 4, 680-681.

Biggar, W. D. \& Sturgess, J. M. (1976). Peroxidase activity of alveolar macrophages. Laboratory Investigation 34, 31-42.

Biggar, W. D., Buron, S. \& Holmes, B. (1976). Bactericidal mechanisms in rabbit alveolar macrophages : evidence against peroxidase and hydrogen peroxide bactericidal mechanisms. Infection and Immunity 14, 6-10.
BLoch, R. G. (1963). The affect of hyperthyroidism on tuberculosis in the guinea-pig: a possible approach to experimental sarcoidosis. American Review of Respiratory Diseases 87, 525-528.

Daems, W. Th., Wisse, P., Brederoo, P. \& Emeis, J. J. (1975). Peroxidatic activity in monocytes and macrophages. In Mononuclear Phagocytes in Immunity, Infection and Pathology, pp. 57-77. Edited by $\mathbf{R}$. van Furth. Oxford: Blackwell Scientific.

Dannenberg, A. M., Ando, M. \& Shima, K. (1972). Macrophage accumulation, division, maturation and digestive and microbicidal capacities in 
tuberculous lesions. III. The turnover of macrophages and its relation to their activation and antimicrobial immunity in primary BCG lesions and those of reinfection. Journal of Immunology 109, 1109-1121.

Delville, J., Huybrechts-Godin, G. \& JAcQues, P. J. (1976). Germicidal activity of the PIGO system on Mycobacterium leprae, in vitro. Archives internationales de physiologie et de biochimie 84, 604-605.

Demoulin-Brahy, L., Paulus, A., HuybrechtsGodin, G. \& JACQUES, P. J. (1975). Germicidal activity of a polyenzymic system on various exoplasmic parasites in vitro. Journal of the Reticuloendothelial Society 18, 14a.

Draper, P. \& Hart, P. D'A. (1975). Phagosomes, lysosomes and mycobacteria: cellular and microbial aspects. In Mononuclear Phagocytes in Immunity, Infection and Pathology, pp. 575-589. Edited by $R$. van Furth. Oxford: Blackwell Scientific.

Hsu, H.-S. \& KaPral, F. A. (1960). The suppressed multiplication of tubercle bacilli within macrophages derived from triiodothyronine-treated guinea-pigs. American Review of Respiratory Diseases 81, 881-887.

JACKetT, P. S., ABer, V. R. \& LoWrie, D. B. (1978). Virulence and resistance to superoxide, low pH and hydrogen peroxide among strains of $\mathrm{Myco-}$ bacterium tuberculosis. Journal of General Microbiology 104, 37-45.

KLEBANOFF, S. J. (1965). Inactivation of estrogen by rat uterine preparations. Endocrinology 76, 301311.

KLEBANOFF, S. J. (1967). Iodination of bacteria: a bactericidal mechanism. Journal of Experimental Medicine 126, 1063-1078.

KLEBANOFF, S. J. (1970). Myeloperoxidase-mediated antimicrobial systems and their role in leukocyte function. In Biochemistry of the Phagocytic Process, pp. 89-110. Edited by G. J. Schultz. Amsterdam and London: North-Holland.

KLEBANOFF, S. J. (1975). Antimicrobial mechanisms in neutrophilic polymorphonuclear leukocytes. Seminars in Haematology 12, 117-142.

KLEBANOFF, S. J. \& HAMON, C. B. (1972). Role of myeloperoxidase-mediated antimicrobial systems in intact leukocytes. Journal of the Reticuloendothelial Society 12, 170-196.

Klebanoff, S. J. \& Hamon, C. B. (1975). Antimicrobial systems of mononuclear phagocytes. In Mononuclear Phagocytes in Immunity, Infection and Pathology, pp. 507-529. Edited by $\mathbf{R}$. van Furth. Oxford: Blackwell Scientific.

KlebANOFF, S. J. \& LuEbKe, R. G. (1965). The antilactobacillus system of saliva. Role of salivary peroxidase. Proceedings of the Society for Experimental Biology and Medicine 118, 483-486.

LEHRER, R. I. (1970). The fungicidal activity of human monocytes: a myeloperoxidase-linked mechanism. Clinical Research 18, 408.

Lepper, A. W. D. \& Hart, P. D'A. (1976). Peroxidase staining in elicited and nonelicited mononuclear peritoneal cells from BCG-sensitized and nonsensitized mice. Infection and Immunity 14, 522-526.

LowRie, D. B., JACKeTt, P. S. \& RatClifFe, N. A. (1975). Mycobacterium microti may protect itself from intracellular destruction by releasing cyclic AMP into phagosomes. Nature, London 254, 600602.

LURIE, M. B. (1964). Resistance to Tuberculosis: Experimental Studies in Native and Acquired Defensive Mechanisms. Cambridge, Massachusetts: Harvard University Press.

Meynell, G. G. (1961). Phenotypic variation in bacterial infection. Symposia of the Society for General Microbiology 11, 174-195.

Mitchison, D. A., Selkon, J. B. \& Lloyd, J. (1963). Virulence in the guinea-pig, susceptibility to hydrogen peroxide, and catalase activity of isoniazid-sensitive tubercle bacilli from South Indian and British patients. Journal of Pathology and Bacteriology 86, 377-386.

Nodine, J. H., Yoshizawa, H., Weiss, W., Stein, S. C., Guth, R. \& Tummillio, M. (1959). The effect of L-triiodothyronine in pulmonary tuberculosis: a pilot study. American Journal of Medical Sciences 237, 27-41.

Reiter, B., Pickering, A. \& Oram, J. D. (1964). An inhibitory system - lactoperoxidase, thiocyanate, peroxide - in raw milk. In 4th International Symposium on Food Microbiology, pp. 297-305. Edited by N. Molin. Stockholm: Almqvist and Wiksell.

Sbarra, A. J., Selvaraj, R. J., Paul, B. B., ZGLICZynski, J. M., Poskitt, P. K. F., Mitchell, G. W. \& LouIs, F. (1976). Chlorination, decarboxylation and bactericidal activity mediated by the MPO- $\mathrm{H}_{2} \mathrm{O}_{2}-\mathrm{Cl}^{-}$system. In The Reticuloendothelial System in Health and Disease, pp. 191203. Edited by S. M. Reichard, M. R. Escobar and H. Friedman. New York and London: Plenum Press.

Sbarra, A. J., Selvaraj, R. J., Paul, B. B., Poskitt, P. K. F., Mitchell, G. W., Louis, F. \& AsBell, M. A. (1977). Granulocyte biochemistry and a hydrogen peroxide-dependent microbicidal system. In The Granulocyte: Function and Clinical Utilization, pp. 29-48. Edited by T. J. Greenwalt and G. A. Jamieson. New York: A. R. Liss.

SPeCTOR, W. G. (1975). The dynamics of granulomas and the significance of epithelioid cells. Pathologie et biologie 23, 437-439.

WInsLOW, C.-E. \& WALKER, H. H. (1939). The earlier phases of the growth cycle. Bacteriological Reviews 3, 147-186. 